\title{
Inter Vivos Gift as Land Inheritance Mechanism for FELDA Land Holding
}

\author{
Nasrul Hisyam Nor Muhamad, ${ }^{1,2}$, Mohd Khairy Kamarudin ${ }^{2}$, Mohd Zamro Muda ${ }^{3}$, Noor Lizza Mohamed Said ${ }^{3}$, \\ Nik Mohd Zaim Ab Rahim² \& Monika@ Munirah Abd Razzak ${ }^{4}$ \\ ${ }^{1}$ Center of Research for Fiqh Science \& Technology (CFiRST), Faculty of Social Sciences and Humanities, \\ Universiti Teknologi Malaysia, Johor, Malaysia \\ ${ }^{2}$ Academy of Islamic Civilisation, Faculty of Social Sciences and Humanities, Universiti Teknologi Malaysia, \\ Johor, Malaysia \\ ${ }^{3}$ Department of Syariah, Faculty of Islamic Studies, Universiti Kebangsaan Malaysia, Selangor, Malaysia \\ ${ }^{4}$ Department of Al-Quran and Al-Hadith, Academy of Islamic Studies, Universiti Malaya \\ Correspondence: Nasrul Hisyam Nor Muhamad, Center of Research for Fiqh Science \& Technology (CFiRST), \\ Academy of Islamic Civilisation, Faculty of Social Sciences and Humanities, Universiti Teknologi Malaysia, \\ Johor, Malaysia. Tel: 60-7-555-7622. E-mail: nasrul@utm.my
}

Received: February 10, 2020

doi:10.5539/jpl.v13n2p226
Accepted: March 10, $2020 \quad$ Online Published: May 27, 2020

URL: https://doi.org/10.5539/jpl.v13n2p226

\begin{abstract}
This study aims to identify the key points of the FELDA land inheritance issues and their possible solutions. Land (Group Settlement Areas) Act 1960 was analyzed as it is the main act that regulates FELDA land management. This study discovered that Section 14 limits the land holding to not more than two holders while Section 15 prohibits subdividing or partitioning over FELDA land holding. An administrator is appointed to manage the land on behalf of other heirs and this practice poses risk as the administrator may fail to execute the trust. Hence, inter vivos gift is proposed to address this problem. It was also found that status of FELDA land holding is considered as 'Conditional Holding' since it limits the number of registered holders and authorisation to inherit the FELDA land to the second FELDA settlers generation This study concluded that inter vivos gift is legal and this is evidenced from the Section 215, National Land Code 1965 which demonstrates that FELDA land holding can be transferred to the second generation via 'Form 14A' at the land offices with the consent from the State Authority and FELDA management as specified in the Land (Group Settlement Areas) Act 1960.
\end{abstract}

Keywords: inter vivos gift, FELDA land holding, inheritance, administrators, FELDA settlers

\section{Introduction}

In early 1950s, majority of land development was controlled by multinational corporations, while Malayans (now Malaysians) only managed small and uneconomical pieces of land. As a result, the Malaysian government established Federal Land Development Authority (FELDA) on July 1st, 1956 through the Land Development Act (Ordinance No.2 of 1956). Historically, the establishment has been a major driver of the urbanization of the rural areas by settling new areas for rubber and oil palm plantations (Leong Fee, 1985; Mehmet, 1982; Sutton, 1989; Sutton \& Buang, 1995). Although other countries such as Indonesia, Sri Lanka and Nepal have their own land settlement planning, they have scarce land sources. However, in the context of Malaysia, the government has given 8 to 10 acres for each FELDA settler (Thapa \& Weber, 1989).

The main objectives of FELDA are to focus on resettlement schemes for the landless person and to reduce rural poverty (Barau \& Said, 2016; Saadun et al., 2018). To date, FELDA is the world's biggest Crude Palm Oil (CPO) producer, with an output of 3.1 million tons annually (Tong, 2017) and one of the most effective land settlement schemes in the world (Kamaruddin, 2018). In order to achieve the objectives, FELDA settlers must be Malaysian citizens and do not have any land except less than two acres or one lot of urban land for residential or both as set out in Section 19, Land (Group Settlement Areas) Act 1960 (Kadimi, 2006; Mat Som, 2003).

Settlers of this scheme were assigned 8 to 10 acres of agricultural land for plantation and half an acre for residences. They accepted credit from the government for forest clearance costs and they are made compulsory to reimburse this credit within 15 years. They are known as the first FELDA settlers generation. While, the 
second FELDA settlers generation can be defined as children to the first settlers who involve in the FELDA settlement scheme (Barau \& Said, 2016; Md Yassin, Shafii, Shareh Musa, \& Bakri, 2017).

Although the FELDA settlers live in rural areas, numerous modern and complete infrastructure facilities have been provided such as electricity, clinics, water and school (Abdul Malek, Abdul Razak, Salman, Mohd Nor, \& Abdullah, 2012). However, some of the second FELDA generation have migrated to city to pursue better life as a result of poor development and production, lack of job prospects and inability to sustain their daily expenditure. This matter typically happens for those who have higher education level that motivates them to migrate, meanwhile others who have low education will stay in FELDA (Azman et al., 2014; Idris, 2004). Thus, FELDA population and productive manpower to manage the plantation decline progressively. The situation is worsening when majority of the first FELDA generation, are at old age and have poor health conditions (Che Din et al., 2014; Fredericks, 2012; Md Yassin et al., 2017; Mohamed et al., 2019; Nik Sazila et al., 2018; Suhaili \& Rahim, 2018).

Therefore, it can be seen that the second generation is the key factor to ensure FELDA land could be developed continuously (Md Hashim, Abdul Hamid, Abdullah, \& Alias, 2009). Various schemes have been promoted by FELDA to encourage them to stay. For instance, entrepreneurship and education programs have been introduced to curb migration among second generations and to develop FELDA constantly (Abd Aziz, Wan Hassan, \& Saud, 2012; Mohamad Radzi, Mohd Nor, \& Mohezar Ali, 2017; Mohamed et al., 2019; O'Donnell, Mansor, Yogeesvaran, \& Rashid, 2017; Selamat, Hayrol Aziz, Anuar, Azmi, \& Endut, 2015, 2017). At the same time, Malaysian government is also committed in offering residential construction support to the second generation which enables them to remain in FELDA (Economic Plan Unit, 2015).

Furthermore, this second generations is also vital to guarantee the sustainability of FELDA land through inheritance as they will succeed the first FELDA settler generation. Yet, the major problem of FELDA land inheritance is the restriction in the Land (Group Settlement Areas) Act 1960 which restricts only two registered names as land holders (Kamarudin \& Abdullah, 2016; Md Yassin et al., 2017; Mohamad et al., 2014; Mohamad, Muslim, Wan Hassan, Umar, \& Mamat, 2019; Mohamed Hasnan, Wahid, Muda, \& Mohd Yusuf, 2017). It poses difficulty and dispute among legal heirs in determining who are the most eligible land holder (Suhaili \& Rahim, 2018). Consequently, from 44170 death cases in FELDA between 1960 to 2016, there are 8872 cases that are still unmanaged by the second generation (Mohamed Hasnan et al., 2017). If the inheritance issue is remained unsettled, the goals of FELDA for land development and eradicating poverty will not be realized. Hence, in this work, relevant act and legislation are analyzed to identify key points of the inheritance issue and potential solutions. This study aims to propose inter vivos gift as an alternative method of inheritance by taking into account the impact of conventional inheritance practice to the FELDA settlers and their next generations.

\section{Inheritance Issues of FELDA Land}

During the early FELDA land resettlement, the settlers did not directly own the land individually after they had explored a new FELDA land area. There are slight differences between rubber plantations and oil palm plantations in terms of land holding scheme. The 'Full Holding' for rubber plantation will only be given after the settlers clear all their debts. On the other hand, for oil palm plantation, 'Full Holding' will not be given to the settlers even after they have cleared all the debts due to 'Block System'. This means that every 20 settlers are commonly allocated an area of 200 acres ( 80 hectares) for their plantation collectively and each settler cannot specify which part they belong to as 'Letter of Holding' was issued to a 200 acre land with 20 names of settlers (Abdul Hamid, 2000; Mat Hussain \& Nor Muhamad, 2013).

Settlers will be entitled to at least one residential lot and one plantation lot. Accordingly, the land holding is a 'Stranded Holding' (hak milik berangkai) in which the settlers hold inseparable holding on residential and agricultural lot (Suhaili \& Rahim, 2018). The status of 'Letter of Holding' that is issued by State Authority to all FELDA land settlers is 'Leasehold' for 99 years (Mohamad et al., 2014) as underlined by Section 11(1), (3) and (4), Land (Group Settlement Areas) Act 1960.

The arising issue on FELDA land holding is the restriction of interest and condition imposed by the Land (Group Settlement Areas) Act 1960, even though land settlement is allowed by the National Land Code 1965. The restriction regarding to FELDA land holding is as stipulated in Section 15, Land (Group Settlement Areas) Act 1960 which this FELDA land could not be subdivided or partitioned. In the context of inheritance estate, one of the most important restrictions is Section 14 which limits the land holding to not more than two holders. This section clearly complicates the process of inheritance if the settler has more than two heirs.

Thus, in the conventional practice, one or two administrators will be appointed to manage the plantation and share the income derive from plantation activities among legal heirs proportionately. Nonetheless, there are 
many cases in which the appointed administrators fail to execute the trust (Hassan \& Abdul Rashid, 2019; Kamarudin, Abdullah, \& Mohamad, 2015; Mohamed Hasnan et al., 2017). This causes several heirs not to gain any income. There are also some administrators who only hand over half of the income to FELDA and sell another half to outsiders illegally. Consequently, FELDA does not have any records regarding income from the settlers (Arifin \& Hussin, 2015; Mat Hussain \& Nor Muhamad, 2013; Nor Muhamad \& Mat Hussain, 2014). As a result, the main objectives of FELDA land settlement are not achieved and settlers and their heirs still remain living in poverty and unable to contribute to the national economic development.

\section{Inter Vivos Gift for FELDA Land Holding}

Inheritance estate for FELDA settlers is FELDA land holding which covers their plantation land and residential site. As practiced in Malaysia, the deceased settlers will transfer their FELDA land holding through faraid (Islamic inheritance), bequest, inter vivos gift, matrimonial asset (harta sepencarian) and endowment (waqf). Through faraid, bequest and matrimonial asset, the FELDA land holding will be transferred to beneficiaries after the death of settlers. On the contrary, via inter vivos gift, beneficiaries will acquire the FELDA land holding during settlers' lifetime (Kamarudin \& Nor Muhamad, 2018).

Practically, inter vivos gift is a contract of giving voluntarily, without any consideration and enforcement during benefactors' lifetime. Based on the definition, a valid inter vivos gift must be completed during benefactors' lifetime, which becomes effective after 'offer and accept' procedure and 'possession' delivery of the asset. If there are any imposed conditions violate the nature and requirement of inter vivos, that condition is null and void but the inter vivos gift is valid and enforceable (Abdul Ghani \& Ahmad Razali, 2018; Nor Muhamad, Che Yaacob, \& Mat Hussain, 2017; Nor Muhamad et al., 2019; Othman, Mohamed Said, Muda, \& Nor Muhamad, 2017). For instance, the main issue in Re Abdul Rahman bin Hj Ahmad \& Ors [2013] ShLR 51 is 'possession' of inter vivos gift. In this case, the ownership of the asset was not transferred by the benefactors to the beneficiaries during lifetime. At the same time, beneficiaries pay all the utilities and damages. The court decided that inter vivos gift is valid because the asset was occupied, managed and maintained by the beneficiaries. It demonstrates beneficiaries' dominance on the asset, even though the transfer of ownership has not been concluded by the benefactors.

To analyze the position of inter vivos gift for FELDA land holding, this study evaluates the extent to which this practice fulfills the rules and condition of inter vivos gift. There are four main rules for inter vivos gift in which there should be benefactors, beneficiaries, asset and 'offer and acceptance' deliveries (Muhammad Serji \& Shapiee, 2018).

With respect to benefactors, he/she must be an individual with 'legal capacity' to make a transaction. Thus, they must be rational, at puberty, independent and legal owner of the asset (Azhar, Hussain, Badarulzaman, \& Mohd Noor, 2014). In the case of Teh bt Ngah v Limah bt Ismail \& Ors [2011] 4 ShLR 64, the plaintiff demanded for verification of inter vivos gift against a piece of land in Pengadang Buluh, Terengganu which was registered under the name of Ismail bin Mamat (the deceased). The land alleged to have been given to the plaintiff by the deceased during his lifetime. The court allowed plaintiff's application that the deceased was the registered owner of the land. The deceased had fulfilled the conditions of making inter vivos gift because he was the registered owner of the land and free to transfer it to anyone. Conversely, for FELDA land holding, settlers are not absolute holders of FELDA land because that holding is subjected to restriction set by Section 15, Land (Group Settlement Areas) Act 1960. The status of 'Partial Holding' is also demonstrated by 'Letter of Holding' that clearly remarks 'Leasehold' status for 99 years. In addition, if settlers request to transfer their holding, they must acquire consent from the State Authority and FELDA management.

Furthermore, with regard to beneficiaries, they could be anyone, capable to control and accept inter vivos gift. In other words, benefactors transfer the ownership of the asset to the beneficiaries to guarantee them control and they own the inter vivos gift entirely (Ibrahim, 2017). Referring to the court decision in the case of Re Abdul Rahman bin Hj Ahmad \& Ors [2013] 1 ShLR 51, the court stipulated that beneficiaries must be capable and qualified individuals to accept inter vivos gift. However, the beneficiaries have no right to receive FELDA land holding because the registered holder is blocked from transferring it to beneficiaries as referred to Section 14 and 15, Land (Group Settlement Areas) Act 1960.

Next, in term of asset, the main conditions are the asset must exist when the contract is made, determined, recognized by law and owned by the benefactors (Muda, 2009). In this case, asset to be transferred is FELDA land holding. Similar to 'benefactors' and 'beneficiaries' situation, FELDA land holding cannot be transferred due to status of holding that is imposed on the asset based on Section 14 and 15, Land (Group Settlement Areas) Act 1960. 
Lastly, 'offer and acceptance' refers to consent between benefactors and beneficiaries either by words or deeds. It also demonstrates the willingness of benefactors to transfer his/her asset to the beneficiaries as well as the desires of beneficiaries to accept the inter vivos gift (Sarip, Adnan, \& Jusoh, 2017). In the context of inter vivos gift for FELDA land holding, the need to fulfill 'offer and acceptance' does not arise compare to other rules.

Based on aforementioned discussion, generally inter vivos through transfer the holding is blocked by Section 14 and 15, Land (Group Settlement Areas) Act 1960 as the settlers have 'Partial Holding' on FELDA land. Consequently, for settlers who still intend to transfer their holding, it is subjected to the permission by the State Authority and FELDA management. The utmost important motive of this restriction is to maintain the status of FELDA land (Mohamed Hasnan et al., 2017). Deprived by this restriction, the problem of multiple ownerships on one holding will occur as practiced by other types of land except FELDA (Kamarudin, Zaman, \& Meor Razak, 2019). Multiple ownerships will contribute to difficulties to the owners to gain benefits such as agricultural and SME activities due to uneconomic size of land (Ahmad, Jamsari, Nasir, Hehsen, \& Hassan, 2017; Hanif, Azriyati, Abdul-Rahman, Wang, \& Wood, 2015; Kamarudin \& Nor Muhamad, 2018; Mohd Shafiai \& Moi, 2015; Sulong \& Taha, 2016; Taha, Sulong, \& Ayub, 2015).

\section{Status of FELDA Land Holding}

For FELDA land holding, this study argues that the holding status is a significant element as it determines the legal effect of inter vivos gift. In one aspect, FELDA land holding is considered as 'Partial Holding', instead of 'Full Holding' by the settlers (Mohd Yusuf, 2018). Still, this type of status is not an absolute practice and yet debatable. In Malaysian law, theoretically 'Full Holding' can be defined as an individual dominates the physical and usufruct on the asset. 'Full Holding' implies permanent ownership and not bound by any period of time. Such holding can merely be terminated when the asset is damaged, transferred to others or the death of owners. In other words, he/she can arrange and manage the asset freely (Noordin, Ismail, Abd Rahman, Haron, \& Abdullah, 2016).

In the meantime, 'Full holding' takes place in three ways, which are 'control the asset that is not owned by anyone', by 'contract' and 'inheritance'. 'Control the asset that is not owned by anybody' can be done through exploring new areas, hunting and mining. Whereas, 'Full Holding' by a 'contact' means transferring the holding through trading, inter vivos giving and bequeathing. Lastly, holding by 'inheritance' occurs when a person inherits the asset from deceased parents (Nor Muhamad, 2011).

Based on the theory of holding, status of FELDA land holding should be evaluated from various perspectives. FELDA land holding is not considered as 'Full Holding' because of the restriction that must be complied with. Likewise, FELDA land holding is not considered as 'Partial Holding' because FELDA land holding will be inherited by legal heirs after the death of settlers. Furthermore, the settlers have been conferred by State Authority under 'Leasehold' when they have cleared debt to FELDA and settled other payments. FELDA settlers have the right to do anything on their land as long as they do not violate the Land (Group Settlement Areas) Act 1960 such as renovating residential house and hiring outsider to manage the plantation. This point contradicts with the concept of 'Partial Holding'.

Based on these, this study recommends that FELDA land holding is considered as 'Conditional Holding' where the land holding is conferred to settlers with several restrictions in Section 11 and 15, Land (Group Settlement Areas) Act 1960. This land holding cannot be categorized as 'Partial Holding' because partial holding definitely cannot be inherited. Meanwhile, Section 14(2), explicitly permits inheritance to the settler legal heirs which limits only to two beneficiaries.

\section{Rationale of Inter Vivos Gift towards FELDA Land Holding}

This study argues that the appointment of administrators can be problematic in the future. The two administrators represent a number of heirs and must share the income among the heirs. This situation is getting worse when one of the administrators passes away. Other legal heirs must appoint a new administrator. At the same time, the legal heirs of the deceased also have their rights to the inheritance estate. This would be different if the FELDA land holding is transferred as inter vivos gift directly to one or two beneficiaries. The beneficiaries will benefit land settlement efficiently through management and planning for land development and maintenance.

Other than that, inter vivos gift can also address dispute issues among legal heirs in the event of the death of settlers. The conventional method of appointing administrators often causes dissatisfaction among heirs who do not get appointed as administrators. Thus, this method will create more complicated inheritance management compared to inter vivos gift. Through inter vivos gift, the benefactors gain the permission from other legal heirs to complete the transfer process. This will reduce potential disputes among legal heirs, allow the process of 
inheritance estate management become easier and to promote affection among family (Kamarudin et al., 2020).

\subsection{Proposition 1: FELDA Land Inheritance through Appointed Administrator}

This study assumes the first settler has one wife and three sons as illustrated in Table 1. For each son, they have one wife and three (grand) sons. The original share for husband is $1 / 1$. After the death of the husband, the FELDA land holding will be inherited by the wife and three sons. In this case, Son (1) is appointed as the administrator of the land. At the same time, he is responsible to distribute any revenue derived from the plantation activities to his mother and two other brothers according to faraid formula; $1 / 8$ for his mother and $7 / 8$ is shared equally among siblings, 7/24 respectively. Later, the first son passes away and he left one wife and three sons. This poses problem as who will be appointed as the administrator. In this case, the second brother becomes the appointed administrator. He is responsible to distribute the revenue about 7/192 to his sister in law and 119/1728 to each nephew. For illustration, the total revenue of the plantation is RM5000 per month, thus the highest share belongs to Son (2) and Son (3) which is RM1458.33 and the lowest belongs to (Grand) Son (1), (2) and (3) which is RM34.43. This practice eventually causes everyone to get smaller share due to the multiple heirs problem.

Table 1. FELDA Land inheritance through appointment of administrator

\begin{tabular}{|c|c|c|c|c|c|c|}
\hline Heir(s) & $\begin{array}{l}\text { Original } \\
\text { share }\end{array}$ & $\begin{array}{l}\text { Share (Son (1) as } \\
\text { administrator) }\end{array}$ & Heir(s) & $\begin{array}{l}\text { Share to Son (1)'s } \\
\text { heirs (Son (2) as } \\
\text { administrator) }\end{array}$ & Total share & $\begin{array}{l}\text { Total revenue } \\
\text { (RM5,000) }\end{array}$ \\
\hline $\begin{array}{l}\text { Husband } \\
\text { (Dead) }\end{array}$ & $1 / 1$ & $x$ & & & $x$ & \\
\hline Wife & & $1 / 8$ & Mother & $7 / 144$ & $\begin{array}{c}300 / 1728 \\
(25 / 144)\end{array}$ & RM868.05 \\
\hline Son (1) & & $7 / 24$ & (Dead) & & $\mathrm{x}$ & \\
\hline Son (2) & & $7 / 24$ & & & $\begin{array}{c}504 / 1728 \\
(7 / 24)\end{array}$ & RM1458.33 \\
\hline \multirow[t]{5}{*}{ Son (3) } & & $7 / 24$ & & & $\begin{array}{c}504 / 1728 \\
(7 / 24)\end{array}$ & RM1458.33 \\
\hline & & & Wife & $7 / 192$ & $63 / 1728$ & RM182.30 \\
\hline & & & $\begin{array}{l}\text { (Grand) } \\
\text { Son (1) }\end{array}$ & $119 / 1728$ & $119 / 1728$ & RM34.43 \\
\hline & & & $\begin{array}{l}\text { (Grand) } \\
\text { Son (2) }\end{array}$ & $119 / 1728$ & $119 / 1728$ & RM34.43 \\
\hline & & & $\begin{array}{l}\text { (Grand) } \\
\text { Son (3) }\end{array}$ & $119 / 1728$ & $119 / 1728$ & RM34.43 \\
\hline
\end{tabular}

\subsection{Proposition 2: FELDA Land Inheritance through Inter Vivos Gift}

While, in Table 2, this study assumes that there are family members (husband, wife and three sons), share for FELDA land and the total revenue (RM5000). FELDA land holding by husband is $1 / 1$ share. During his life time, husband transfers the share to Son (1). Thus the FELDA land holding belongs to Son (1) absolutely. He will benefit from the FELDA land revenue which is RM5000 and does not have any obligation to share the revenue among other family members through faraid formula. 
Table 2. FELDA land inheritance through inter vivos gift

\begin{tabular}{lllll}
\hline Family members & Share & Family members & Share & Total revenue (RM5000) \\
\hline Husband & $1 / 1$ & Husband & & \\
Wife & & Wife & $1 / 1$ & RM5000 \\
Son (1) & & Son (1) & & \\
Son (2) & & Son (2) & & \\
Son (3) & & Son (3) & & \\
\hline
\end{tabular}

Practically, this FELDA land holding could be transferred directly from benefactors to beneficiaries which involve transfer process through 'Form 14A' instrument at the land offices as stated in Section 215, National Land Code 1965 (Abdul Rashid \& Yaakub, 2010; Muhammad Serji \& Shapiee, 2018). However, this type of transfer may only take place with the consent from the State Authority and FELDA management as stipulated in Land (Group Settlement Areas) Act 1960.

Hence, instead of direct transfer through 'Form 14A', inter vivos gift can be made through documentation. By this method, all the requirements in formatting inter vivos gift should be fulfilled (Noordin et al., 2016). Benefactors may appoint a trustee to perform his/her obligation that is explicitly listed through the Deed of Trust. Thus the holding transfer process is only executed after the death of settlers. The land office will certify this inter vivos gift documentation if there is no objection among legal heirs or after obtaining order from the court to transfer FELDA land holding to beneficiaries. Even though Section 14(2), Land (Group Settlement Areas) Act 1960 allows FELDA land to be jointly held by not more than two holders, this study suggests there should be only a single beneficiary of the FELDA land inheritance through inter vivos to overcome the problem of uneconomic size of land.

\section{Conclusion}

FELDA plays essential role in Malaysia' economic growth particularly in the agricultural sector. Yet the main problem is inheritance by the second generation of settlers. To address this issue, this study has analyzed the laws relating to inheritance of FELDA land and also potential solution. There are two restrictions imposed by the laws namely non-transferability and limited number of beneficiaries that can be registered in FELDA land holding. These restrictions contribute to delays in inheritance management, disputes among legal heirs and potential irresponsibility of appointed administrators. Thus, inter vivos gift is a practical solution which transfers ownership to a single beneficiary as to maintain FELDA's primary objective of eradicating poverty and boosting rural economic development. The next study will need to be conducted by identifying the settlers' willingness to apply this alternative mechanism of FELDA land inheritance. Simultaneously, inheritance seminars and courses should be conducted to disseminate the information about the concept in order to facilitate the process of FELDA land inheritance.

\section{Acknowledgments}

Special thanks to Ministry of Higher Education (MOHE) of Malaysia, Fundamental Research Grant Scheme (FRGS); Universiti Teknologi Malaysia - no. grants: FRGS/1/2014/SSI03/UTM/02/2 \& FRGS/1/2014/SSI03/UTM/02/7 to support this research.

\section{References}

Abd Aziz, N. N., Wan Hassan, W. H. A., \& Saud, N. A. (2012). The effects of urbanization towards social and cultural changes among Malaysian Settlers in the Federal Land Development Schemes (FELDA), Johor Darul Takzim. Procedia - Social and Behavioral Sciences, 68, 910-920. https://doi.org/10.1016/j.sbspro.2012.12.276

Abdul Ghani, F., \& Ahmad Razali, N. (2018). Legal review on hibah (inter vivos gift) in Malaysia: Problems and solutions. Social \& Behavioural Sciences. https://dx.doi.org/10.15405/epsbs.2018.07.02.95

Abdul Hamid, A. F. (2000). Diverse approaches to rural development in Malaysia: The FELDA and Darul Arqam Land settlement regimes. Humnanomics, 16(1), 51-73.

Abdul Malek, J., Abdul Razak, N., Salman, A., Mohd Nor, F., \& Abdullah, M. Y. (2012). Digital inclusion society in Malaysia Felda agricultrual area. Wseas Transacktions on Information Science and Applications, 9(4), 115-124. 
Abdul Rashid, R., \& Yaakub, N. I. (2010). Hibah: Isu pindah milik dan pembatalan hibah hartanah di bawah Kanun Tanah Negara. Syariah Law Reports, 1, 14-29.

Ahmad, M. Y., Jamsari, E. A., Nasir, B. M., Hehsen, A., \& Hassan, W. Z. W. (2017). Flexibility of takharuj principle in solving the inheritance issues. International Journal of Civil Engineering and Technology, 8(811), 867-878.

Arifin, N., \& Hussin, K. (2015). Review on issues and problems of transferring Felda Land ownership. Journal of Management Research, 7(2), 229. https://doi.org/10.5296/jmr.v7i2.6942

Azhar, A., Hussain, M. A., Badarulzaman, M. H., \& Mohd Noor, F. (2014). Pengurusan harta dalam Islam: Perspektif hibah di Malaysia. Journal of Human Development and Communication, 3, 115-128.

Azman, N., Othman, N. H., Abdul Halim, S., Abd Majid, F., Mohd Zain, M. I., Komoo, I., ... Sanusi, Z. A. (2014). Memperkasa kepimpinan ahli akademik Anak Generasi Felda (AGF): Satu analisis daya tahan. Sains Humanika, 3(1), 37-46.

Barau, A. S., \& Said, I. (2016). From goodwill to good deals: FELDA land resettlement scheme and the ascendancy of the landless poor in Malaysia. Land Use Policy, 54, 423-431. https://doi.org/10.1016/j.landusepol.2016.03.009

Che Din, N., Ghazali, S. E., Ibrahim, N., Ahmad, M., Sais, Z., Ghazali, A. R., ... Shahar, S. (2014). Health needs assessment of older people in an agricultural plantation. International Journal of Gerontology, 8(3), 120 126. https://doi.org/10.1016/j.ijge.2013.12.003

Economic Plan Unit. (2015). Eleventh Malaysia Plan 2016 - 2020. Kuala Lumpur, Malaysia: Percetakan Nasional Malaysia Berhad.

Fredericks, L. J. (2012). Exploring the Spatial Dimensions of Rural Development Models in Malaysia 1957-2007. Institutions and Economies, 4(1), 47-62.

Hanif, N.-R., Azriyati, W. N., Abdul-Rahman, H., Wang, C., \& Wood, L. C. (2015). The challenge of rural life nostalgia: Barriers in redevelopment of Malay Reserve Land (MRL) in Klang Valley. City, Territory and Architecture, 2(3), 1-10.

Hassan, S. A., \& Abdul Rashid, R. (2019). A need for regulatory framework of nominated property in Malaysia: An issue of rights and duties of nominee. In M. Mohamad Noor, B. Ahmad, M. Ismail, H. Hashim, \& M. Abdullah Baharum (Eds.), Proceedings of Regional Conference on Science,Technology and Social Sciences (RCSTSS 2016). Singapore: Springer. Retrieved from https://doi.org/10.1007/978-981-13-0203-9_48

Ibrahim, B. (2017). Hibah (gift inter vivos) by parent in favour of some children to the exclusion of the others under Islamic law. Arab Law Quarterly, 31(1), 54-73.

Idris, N. A. (2004). Social mobility amongst the second generation of Felda. Akademika, 64, 83-95.

Kadimi, S. (2006). Inheritance estate distribution with land under Land Act (Group Settlement Act) 1960. In Prosiding Seminar Kebangsaan Pengurusan Harta dalam Islam2 (pp. 41-52).

Kamaruddin, N. (2018). An East Asian Approach to Rural Development: A comparative of the Saemaul Undong and FELDA Programs. Asian International Studies Review, 19(1), 75-98. https://doi.org/10.16934/isr.19.1.201806.75

Kamarudin, M. K., \& Abdullah, A. (2016). Amalan pembahagian faraid di Malaysia. Journal of Global Business and Social Entrepreneurship, 2(3), 11-19.

Kamarudin, M. K., Abdullah, A., \& Mohamad, S. F. (2015). Nomination practice in Malaysia: A review on the requirements and conditions from Islamic perspective. Intercontinental Journal of Finance Research Review, 3(10), 1-7. Retrieved from http://www.icmrr.org/oct_2015/IJFRR/201510201.pdf

Kamarudin, M. K., \& Nor Muhamad, N. H. (2018). Siblings' dispute over parents' transfer: Malaysian case. Journal of Advanced Research in Law and Economics, IX(5(35)), 978-989. https://doi.org/10.14505//jarle.v9

Kamarudin, M. K., Nor Muhamad, N. H., Alma'amun, S., Abdullah, A. H., Saat, S., \& Samurah, N. O. (2020). Inter vivos transfers based on affection for wealth distribution planning in Malaysia. The Journal of Asian Finance, Economics and Business, 7(4), 299-307. https://doi.org/10.13106/jafeb.2020.vol7.no4.299

Kamarudin, M. K., Zaman, N., \& Meor Razak, R. (2019). Analisis tema terhadap keperluan undang-undang 
hibah di Malaysia. Al-Qanatir International Journal of Islamic Studies, 16(1), 1-13.

Leong Fee, W. (1985). Policies for agricultural development in Peninsular Malaysia. Land Use Policy, 2(1), 3040. https://doi.org/10.1016/0264-8377(85)90052-3

Mat Hussain, N., \& Nor Muhamad, N. H. (2013). Mekanisme pembahagian harta pusaka tanah rancangan: Kajian di Felda Taib Andak, Kulai Johor. Kanun, 25(1), 1-21.

Mat Som, K. (2003). Land Act (Group Settlement Area) 1960 \& Development of Felda society. In Seminar Pentadbiran dan Perundangan Tanah.

Md Hashim, B., Abdul Hamid, A., Abdullah, M. S., \& Alias, R. (2009). Socio-economic issues among FELDA settlers in Perlis. Asian Culture and History, 1(2), 113-117.

Md Yassin, A., Shafii, H., Shareh Musa, S. M., \& Bakri, S. N. (2017). Residential property ownership strategy by FELDA second generation. Asian Journal of Environment, History and Heritage, 1(2), 155-164.

Mehmet, O. (1982). Evaluating alternative land schemes in Malaysia: FELDA and FELCRA. Contemporary Southeast Asia, 3(4), 340-360.

Mohamad Radzi, K., Mohd Nor, M. N., \& Mohezar Ali, S. (2017). The impact of internal factors on small business succes: A case of small enterprises under the FELDA scheme. Asian Academy of Management Journal, 22(1), 27-55. https://doi.org/10.21315/aamj2017.22.1.2

Mohamad, Z., Md Noor, R., Tapah, S., Zainal, K., Muslim, N., Umar, A., ... Alias, J. (2014). The implementation of the Milk Al-Manfa'ah concept in Malaysia: Reference to the Group Settlement Area Land Act (1960). Middle-East Journal of Scientific Research, 22(5), 782-788.

Mohamad, Z., Muslim, N., Wan Hassan, W. Z., Umar, A., \& Mamat, M. (2019). Migration from traditional village to group settlement area: AN analysis of felda experience. International Journal of Innovative Technology and Exploring Engineering, 9(1), 729-736. https://doi.org/10.35940/ijitee.A4214.119119

Mohamed Hasnan, N., Wahid, H., Muda, M. Z., \& Mohd Yusuf, M. Y. (2017). Amendment of the GSA Act 2002 and the proposed a model of the estate distribution of Felda. In Persidangan Kebangsaan Ekonomi Malaysia ke-12.

Mohamed, K., Raja Haron, R. M. A., Mohd Hafiz, A. H., Sooryanarayana, R., Ahmad, N. A., Tajudin, A. R., ... Kamarudin, L. A. (2019). Non communicable diseases aong elderly Felda residences in Batang Padang, Perak. Perak Medical Journal, 1(Special issue), 28.

Mohd Shafiai, M. H., \& Moi, M. R. (2015). Financial problems among farmers in Malaysia: Islamic agricultural finance as a possible solution. Asian Social Science, 11(4), 1-16.

Mohd Yusuf, M. Y. (2018). Real estate management among FELDA settlers: Problems and challenges. In Seminar Pengurusan Hartanah Peneroka FELDA. Johor Bahru.

Muda, M. Z. (2009). Instrumen hibah dan wasiat: Analisis hukum dan aplikasi di Malaysia. Jurnal Pengurusan JAWHAR, 3(1), 105-157.

Muhammad Serji, R., \& Shapiee, R. (2018). Issues and legal conflicts related to hibah of immovable properties in Malaysia. Journal of Muwafaqat, 1(1), 84-101.

Nik Sazila, N. A. S., Abdullah, F. A., Mohamed Khadri, N. A., Sidek, S., Abdullah, F. A., Mat, K., ... Rahman, M. M. (2018). The intention level among FELDA youth to re-migrate from city for livestock entrepreneurship: A preliminary study. International Journal of Academic Research in Business and Social Sciences, 8(6), 566-577. https://doi.org/10.6007/IJARBSS/v8-i6/4258

Noordin, N. H., Ismail, M. I., Abd Rahman, M. A. H., Haron, S. N., \& Abdullah, A. (2016). Re-evaluating the practice of hibah trust in Malaysia. Humanomics, 32(4), 418-436. https://doi.org/10.1108/H-05-2016-0044

Nor Muhamad, N. H. (2011). Penyelesaian pindah milik harta bercagar di institusi kewangan: Dari perspektif undang-undang Islam. Kanun, 2, 180-208.

Nor Muhamad, N. H., Che Yaacob, A., \& Mat Hussain, N. (2017). Konsep hibah bersyarat dan aplikasinya dalam perancangan harta. UMRAN International Journal of Islamic and Civilizational Studies, 3(1), 32-41. Retrieved from https://jurnalumran.utm.my/index.php/umran/article/view/251/117

Nor Muhamad, N. H., Kamarudin, M. K., Abdullah, A. H., Sholehuddin, N., Abdul Hamid, M. F., Muhidin, I., \& Abdul Karim, K. (2019). Islamic inter vivos law challenges in Malaysia. Journal of Legal, Ethical and Regulatory Issues, 22(1), 1-6. 
Nor Muhamad, N. H., \& Mat Hussain, N. (2014). Pembahagian harta pusaka Felda: Perspektif masyarakat Islam Felda Taib Andak. Jurnal Teknologi (Social Sciences), 66(1), 27-33.

O’Donnell, M., Mansor, N. B., Yogeesvaran, K., \& Rashid, A. (2017). Organisational change and success in a government enterprise: Malaysia's Federal Land Development Agency. Economic and Labour Relations Review, 28(2), 234-251. https://doi.org/10.1177/1035304617706847

Othman, N. S., Mohamed Said, N. L., Muda, M. Z., \& Nor Muhamad, N. H. (2017). Analisis kes amalan hibah bersyarat di Malaysia. Islamiyyat, 39(2), 135-142.

Saadun, N., Lim, E. A. L., Mohd Esa, S., Ngu, F., Awang, F., Gimin, A., ... Azhar, B. (2018). Socio-ecological perspectives of engaging smallholders in environmental-friendly palm oil certification schemes. Land Use Policy, 72(January), 333-340. https://doi.org/10.1016/j.landusepol.2017.12.057

Sarip, M. M., Adnan, A., \& Jusoh, M. M. (2017). Tahap pengetahuan hibah hartanah dalam perancangan harta orang Islam. Journal of Islamic, Social, Economics, and Development, 2(5), 79-89.

Selamat, N. H., Hayrol Aziz, F. S., Anuar, A., Azmi, Z., \& Endut, N. (2015). Gender, space and entrepreneurship: A case study of FELDA women entrepreneurship in Johor, Malaysia. In N. Samat, S. Mohd, K. S. Leng, A. Abdul Rahim, \& S. Ghazali (Eds.), Proceedings of International Conference on Development and Socio Spatial Inequalitues (pp. 74-81). Penang: School of Humanities, USM.

Selamat, N. H., Hayrol Aziz, F. S., Anuar, A., Azmi, Z., \& Endut, N. (2017). Gendered space in entrepreneurship: A study of women entrepreneurship in Felda. International Journal of Environment, Society and Space, $5(1), 31-43$.

Suhaili, S., \& Rahim, F. (2018). The second-generation touth of Felda (G2F): Position and socioeconomic issues. Jurnal Perspektif, 1(Special Issues), 41-55.

Sulong, J., \& Taha, M. M. (2016). Implications of multiple land ownership in Malaysia. International Journal of Social Science and Humanity, 6(5), 2014-2017.

Sutton, K. (1989). Malaysia's FELDA land settlement model in time and space. Geoforum, 20(3), 339-354. https://doi.org/10.1016/0016-7185(89)90008-0

Sutton, K., \& Buang, A. (1995). A new role for Malaysia's FELDA. Geography, 80(2), 125-137.

Taha, M. M., Sulong, J., \& Ayub, M. N. (2015). Pemilikan bersama tanah pusaka: Realiti, masalah dan cabaran. ESTEEM Academic Journal, 11(2), 47-59.

Thapa, G. B., \& Weber, K. E. (1989). Land settlement in Tropical Asia. Habitat International, 13(4), 147-160.

Tong, Y. S. (2017). Vertical specialisation or linkage development for agro-commodity value chain upgrading? The case of Malaysian palm oil. Land Use Policy, 68(August), 585-596. https://doi.org/10.1016/j.landusepol.2017.08.020

\section{Copyrights}

Copyright for this article is retained by the author(s), with first publication rights granted to the journal.

This is an open-access article distributed under the terms and conditions of the Creative Commons Attribution license (http://creativecommons.org/licenses/by/4.0/). 